\title{
Internal Relations and the Possibility of Evil
}

On Cavell and Monstrosity

\section{Martin Shuster}

\section{(2) OpenEdition \\ Journals}

Electronic version

URL: http://journals.openedition.org/ejpap/901

DOI: 10.4000/ejpap.901

ISSN: 2036-4091

Publisher

Associazione Pragma

\section{Electronic reference}

Martin Shuster, «Internal Relations and the Possibility of Evil », European Journal of Pragmatism and American Philosophy [Online], II-2 | 2010, Online since 21 December 2010, connection on 23 April 2019. URL : http://journals.openedition.org/ejpap/901 ; DOI : 10.4000/ejpap.901

This text was automatically generated on 23 April 2019.

\section{(c) $($ ) $\odot$ (8)}

Author retains copyright and grants the European Journal of Pragmatism and American Philosophy right of first publication with the work simultaneously licensed under a Creative Commons AttributionNonCommercial-NoDerivatives 4.0 International License. 


\title{
Internal Relations and the Possibility of Evil
}

On Cavell and Monstrosity

\author{
Martin Shuster
}

\section{Introduction}

1 In a suggestive and seemingly commonplace claim Cavell points out that "mere morality is not designed to evaluate the behavior and interactions of monsters" (CR 265). ${ }^{1}$ I say suggestive and commonplace because such a thought recurs at crucial points in The Claim of Reason. Indeed, ultimately, Cavell writes in a parenthetical that:

To understand Nazism, whatever that will mean, will be to understand it as a human possibility; monstrous, unforgiveable, but not therefore the conduct of monsters. Monsters are not unforgiveable, and not forgiveable. We do not bear the

right internal relation to them for forgiveness to apply. (CR 378)

2 Now, as far as I can tell this line of thinking raises two distinct questions, the first lexicographic, the other theoretical. Starting with the former, it is important to understand what Cavell means by "internal relation." On the point of the latter, there is the age-old, perhaps even tired question about the nature of evil. Roughly, the question centers on whether we take evil to be a distinct something (e.g. a malum metaphysicum) or whether we take it to be a lack or privation of something (i.e. a nothing) like "the good," or more neutrally, e.g., existence. ${ }^{2}$ To return to the prior point about internal relations, I think it is especially significant to take stock of this term and its connection to Cavell's moral perfectionism because it allows us to see that the notion of internal relations is not something that Cavell simply tacks onto his moral perfectionism, but rather the notion of internal relations fundamentally expressed his moral perfectionism.

Ultimately, my argument here will be that not only does (1) Cavell's moral perfectionism present a more interesting (or perhaps even novel) answer to the question of evil, but 
that it does so by (2) fundamentally undermining the basis through which the question of whether evil is a privation or a positive force or object can arise in the first place.

\section{Internal Relations}

We can begin to elaborate these points by making sense of what Cavell means by "internal relation." This term occurs seven times in the Claim. I quote all but one of them here: ${ }^{3}$

What he [a conservative in a debate about abortion] wants is for the embryo to be seen as a human being: he wants the internal relation between human embryos and human beings to strike you. (CR 373)

$\mathrm{He}$ [the slave-owner] is rather missing something about himself, or rather something about his connection with these people, his internal relation with them, so to speak. (CR 376)

He [again, the slave-owner] means, indefinitely, that there are kinds of humans. (It is, I take it, to deny just this that Marx [...] speaks of man as a species-being. To be human is to be one of humankind, to bear an internal relation to all others). (CR 376)

Whether I am struck by likeness or difference, however, the basis of the surprise is the stability of the human frame, as it were, under countless inflections - the internal relation between each body and each other. (CR 395)

The logical space is so vast between kinds of objects [...] Whereas human beings, by contrast, are all alike; each bears an internal relation to all others. (CR 442)

You do not claim [...] to go around every day in roughly Othello's frame of mind? Not exactly. But I claim to see how his life figures mine, how mine has the makings of his, that we bear an internal relation to one another; how my happiness depends upon living touched but not struck by his problems [...]. (CR 453)

Now, the employment of this term here is initially puzzling. As G. E. Moore had pointed out roughly sixty years prior with his attack on Bradley, "it is by no means easy to make out" what may be meant by the notion of an internal relation. ${ }^{4}$ Of course, 'internal relations' have an elaborate, perhaps even sordid, philosophical history. Most prominently, I am thinking exactly of the aforementioned revolt by Russell and Moore against Bradley and Green on the point of internal relations. ${ }^{5}$ To best understand Cavell's employment of internal relations, however, I think we can focus on Wittgenstein's use of the term in reaction to Russell's and Moore's use of it. Indeed, given Cavell's relationship to Wittgenstein, I don't think it is implausible to suggest that the Wittgensteinian heritage is the one most relevant.

Dropping our anchor here, however, proves not to be entirely easy, since Wittgenstein uses the notion as early as the Tractatus and recent Wittgenstein interpretation has been divided on how to understand Wittgenstein on the notion of internal relations in the Tractatus. ${ }^{6}$ Without entering into this debate, I do want to pick out one striking formulation from the Tractatus. There, Wittgenstein writes that:

4.123: A property is internal if it is unthinkable that its object should not possess it (This shade of blue and that one stand, eo ipso, in the internal relation of lighter to darker. It is unthinkable that these two objects should not stand in this relation). ${ }^{7}$

Skipping to Wittgenstein's later work, the term 'internal relation' occurs only once in the Investigations; there Wittgenstein writes:

The colour of the visual impression corresponds to the colour of the object (this blotting paper looks pink to me, and is pink) - the shape of the visual impression to the shape of the object (it looks rectangular to me, and is rectangular) - but what I 
perceive in the dawning of an aspect (Aspekt) is not a property of the object, but an internal relation between it and other objects. ${ }^{8}$

On the next page, Wittgenstein points out:

The concept of an aspect is akin (verwandt) to the concept of an image (Vorstellung) [...] Seeing an aspect and imagining are subject to the will (Wille). There is such an order as "Imagine this," and also: "Now see the figure like this"; but not: "Now see this leaf green."

9 We can see from these quotations that there is a certain continuity in Wittgenstein's understanding of internal relations - at least on this point - namely that the notion of internal relations, at least as far as it can best be illustrated, is always closely linked to the perception of colors. An internal relation is understood in such a way that in order to understand one concept (e.g. red), I must understand another (e.g. pink), and vice versa.

\section{Forms of Life}

10 A particular sort of holism (perhaps even idealism) is certainly what underwrites Wittgenstein's later thinking on the matter (and this later thought is the one that carries the most significance for Cavell). This Wittgensteinian backdrop, although a sort of holism, is not however, at least on the point of internal relations, one that succumbs to the criticisms that Russell launched against Bradley's holistic idealism. Russell had argued that a doctrine of internal relations commits one to holding "that every relation is really constituted by the natures of the terms or of the whole which they compose, or merely that every relation has a ground in these natures." ${ }^{10}$

11 Wittgenstein's point - certainly by the time of the Investigations - is that the picture behind Russell's critique is one that itself must be abandoned. It is not that there is some ontological whole that stands behind relations constituting or grounding them (i.e. Bradley, on Russell's view), nor is it the case that relations are entirely contingent (as Russell's doctrine of external relations argued). Rather, the picture that makes either of these positions plausible is itself precisely undermined by Wittgenstein's entire later philosophical outlook. While relations are ultimately conceptual, our concepts are neither defined solely by something like an outside (e.g. reality), nor solely by something like an inside (e.g. mind), nor even by some relation between the two. ${ }^{11}$ Instead, as Cavell points out, for Wittgenstein, the "gap between mind and world is closed, or the distortion between them straightened, in the appreciation and acceptance of particular human forms of life, human 'convention"' (CR 109). To begin to understand this point, we can remind ourselves that Wittgenstein claims that: "An internal relation is never a relation between two objects, but you might call it a relation between two concepts. And a sentence asserting an internal relation between two objects, such as a mathematical sentence, is not describing objects but constructing concepts." ${ }^{12}$ Concept construction, in turn, according to Wittgenstein, is not something that occurs merely in reaction to some "external" reality, nor merely by some "frictionless spinning in a void." ${ }^{13}$ Our concepts owe themselves to our forms of life. ${ }^{14}$ (As Wittgenstein puts the point: "The person who cannot play this game does not have this concept." ${ }^{15}$ )

12 To return to the discussion of an aspect, we can get a better grasp on what Wittgenstein's notion of internal relations may signify for Cavell by asking what it would mean to have 'aspect blindness,' to have an ignorance of an internal relation. On this point, Wittgenstein proposes that we could indeed imagine someone having a sort of "aspect 
blindness": "The question now arises: Could there be human beings lacking in the capacity to see something as something - and what would that be like?"16 Framed in this way, it is explicit that this entire Wittgensteinian theme is meant to connect to Cavell's discussion of "soul-blindness" (CR 378 - a point Cavell himself makes on CR 355).

In elaborating 'aspect blindness,' Wittgenstein points out that "the 'aspect-blind' will have an altogether different relationship to pictures from ours." ${ }^{17}$ In turn, Wittgenstein draws an analogy between having a 'musical ear' and aspect blindness. He asks us to imagine what it means to 'experience' words. What I take Wittgenstein to be after with these suggestions is that 'aspect-blindness' is, as he states, in part, subject to the will (albeit with an important caveat to the notion of will, elaborated below): I can take this picture as a picture of this or of that (e.g. the duck or the rabbit), but my will is also subject to the form of life that I inhabit (e.g. if I have no notion of a duck because no such creatures exist, then that aspect is unavailable to me). As Wittgenstein will state at the end of this discussion: "What has to be accepted, the given, is - so one could say - forms of life." 18

Before getting a grip on how forms of life is being employed here, and before returning to Cavell, it is important to highlight several characteristics of 'soul-blindness' over and beyond 'aspect-blindness.' Most fundamentally, Wittgenstein points out that: 'II cannot know what is going on in him' is above all a picture. It is the convincing expression of a conviction. It does not give the reasons for the conviction. They are not readily accessible." ${ }^{19}$ The point, as far as Cavell is concerned (i.e. as far as Cavell's Wittgenstein is concerned), is that in the case of 'soul-blindness' it is simply not possible, as an agent, for me to lack others, to be entirely alone. I take this point to be, at least in part, another consequence of the way in which Cavell interprets Wittgenstein's private language argument. Cavell writes:

I think one moral of the Investigations as a whole can be drawn as follows: The fact, and the state, of your (inner) life cannot take its importance from anything special in it. However far you have gone with it, you will find that what is common is there before you are. The state of your life may be, and may be all that is, worth your infinite interest. But then that can only exist along with a complete disinterest toward it. The soul is impersonal. (CR 361)

My own self is intimately dependent on others: it is in this sense that Cavell means the "soul is impersonal." Not impersonal in the sense that it is not mine, but impersonal in the sense that it can only belong to me in and through a relation to others. More specifically, the argument here and elsewhere is that, through and through, my innermost private thoughts and moments are always already inflected through and saturated by language, namely a language that is always fundamentally inherited (perhaps even stolen, as Cavell proposes in places). There is and can be nothing of, in, or through the self that is not in this way configured: privacy is itself always a function of the common heritage of language and thereby our relation not only to language, but to others (whether overtly in the form of word projection and its success and/or failure or covertly in the contours of our world.) So, where in the case of 'aspect blindness,' it is possible to lack certain particulars, it is impossible in the case of 'soul blindness' to lack particular others.

Such an argument about language, ourselves, and others, however, raises all of the various complex questions about how to conceive of such a relation and how such a relation (as much to language as to others) works (and fails to work), both philosophically and in lived experience. ${ }^{20}$ The answers to such questions are, at least in rubric, found in 
Cavell's elaboration of Wittgenstein's notion of a form of life. Who I am is defined as much by the various social claims, motivations, and influences (among other things) that congeal into what Wittgenstein calls a "practice," ${ }^{21}$ as it is defined by who I take myself to be in response to such practices. In turn, these practices are more than mere agreements within a community or individual interpretations, ${ }^{22}$ they are something we are already always engaged in, immersed in, and in the midst of. Agreement is already always continually negotiated, perhaps and often at levels too complex to perceive, while interpretation itself cannot exist outside of the practices of a community: it is also already always dependent on our practices. We can think here precisely of what Cavell had in an earlier essay called the "whirl of organism." ${ }^{23}$ Not only are these practices constantly shifting in the ways in which we do and do not negotiate our linguistic and social boundaries, but they are impacted as much by simple brute facts like that we will die, we require food, we have sex, we excrete, we need to breathe, we get sick, and so forth. ${ }^{24}$

There is, then, a seamless interpenetration between our particular surroundings and the ways in which we see the things in and of those surroundings. Wittgenstein is explicit about this point when he writes that: "Something is 'grey' or 'white' only in a particular surrounding (Umgebung)." ${ }^{25}$ In turn, forms of life, surroundings, and our practices are all mutually implicated within one another. A forceful example is presented in $\$ 250$ of the Investigations, when Wittgenstein asks:

Why can't a dog simulate pain? Is he too honest? Could one teach a dog to simulate pain? Perhaps it is possible to teach him to howl on particular occasions as if he were in pain, even when he is not. But the surroundings which are necessary for this behaviour to be real simulation are missing. ${ }^{26}$

Our surroundings, our forms of life, indeed we (i.e. I) require an other. ${ }^{27}$ According to Cavell, someone who is 'soul-blind' wants to deny or overlook this aspect of herself. She willfully proposes a picture of herself that excludes the other, that promotes a fantasy of radical independence. Or, she is incapable of seeing a picture in which the other appears. This is what I take Cavell to mean when he writes that:

The block to my vision of the other is not the other's body but my incapacity or unwillingness to interpret or to judge it accurately, to draw the right connections. The suggestion is: I suffer a kind of blindness, but I avoid the issue by projecting this darkness upon the other [...] Aspect-blindness is something in me failing to dawn. (CR 368-369)

Cavell continues, drawing the aforementioned connection to the duck-rabbit, by pointing out that: "We may say that the rabbit-aspect is hidden from us when we fail to see it. But what hides it is then obviously not the picture (that reveals it), but our (prior) way of taking it, namely in its duck-aspect" (CR 369). Cavell's point is that in the case of 'soulblindness' it is impossible, unless one has actively willed it (and this must be qualified in a very important way shortly), for an other or others to be missing (as opposed to, e.g., in the case where a duck-aspect may be missing in a world without ducks - i.e., in a world without the obvious possibility of a duck aspect). The point is that I am who I am always only in relation to an other (whereas I could easily be who I am in a world that lacked ducks or rabbits, or even both). One explicit moment (among countless others) where Cavell makes this point is when he writes:

I do not know in advance how deep my agreement with myself is, how far responsibility for the language may run. But if I am to have my own voice in it, I must be speaking for others and allow others to speak for me. The alternative to speaking for myself representatively (for someone else's consent) is not: speaking for 
myself privately. The alternative is having nothing to say, being voiceless, not even mute. (CR 28)

How to "cash out" this proposal (whether, e.g., to understand it dialectically or nondialectically or how to understand the mechanics and nature of Cavellian acknowledgment or the proposal of community and communal politics that it entails) is a complex question that I simply cannot pursue here. The only point I want to stress is that Cavell wants to invoke precisely the idea that who I am owes itself to my relation to an other (again, at this point taken neither dialectically nor non-dialectically). ${ }^{28}$

Now, when I say that soul-blindness can only exist because of a process of will, whereas aspect blindness can exist by a process of will or by the contingencies of affairs, I believe that it is crucial to understand that will here is not some simple mechanism of choice. Rather, owing to the picture of agency that I sketched above (that the notion of forms of life proposes), the notion of will itself begins to look radically different. One way to understand this point is to grasp that, owing to the saturation between inside and outside, the relationship between our vision of the world and our choices within the world becomes reconfigured. This is what I take to be the import of Wittgenstein's point that: "Seeing an aspect and imagining are subject to will. There is such an order as 'Imagine this,' and also: 'Now see the figure like this'; but not: 'Now see this leaf green'." 29 Much in the same way that we do not have an option of seeing in color (unless we are color-blind, in which case we do not have the option of seeing in black and white), so we also do not have the option of being who we are without others. We can however (and certainly, oftentimes unfortunately, and all-too-easily do) train or allow ourselves (whether intentionally or unconsciously, knowingly or unknowingly) to see not only a duck instead of a rabbit, but a slave instead of a person, or an object instead of a subject. The relationship between our vision and our moral commitments, then, is such that we need not (indeed cannot) choose, theoretically, between a demurral to treat someone as other than a slave owing to an incapability of seeing them as more than a slave and an incapacity to see them as more than a slave owing to a demurral to treat them as more than a slave. The two are one and the same. This is what Cavell means when he writes that: "What he [the slave-owner] really believes is not that slaves are not human beings, but that some human beings are slaves [...] this man sees certain human beings as slaves, takes them for slaves" (CR 375). ${ }^{30}$ When Wittgenstein states that seeing an aspect is subject (unterstehen) to will, he has in mind not that our seeing of aspects is always a matter of willing to see it a certain way, but only that it can so be subject, as the German suggests, it can be subordinate to or under the control of our will.

The reason, among other things, that it may often be more difficult to change one's view (let alone someone else's view) of someone from a slave to a non-slave is that such a vision is always bound up with intricate and varied sets of other beliefs, ranging in scope and weight from anything to religion (e.g. manifest destiny or the Curse of Ham) to science (e.g. racial anthropology) to aesthetics (e.g. the "Caucasian" skull of Backenbach) to politics (e.g. secessionism), and so forth. The vision between a duck and a rabbit, although potentially subject to similar sorts of inputs is inflected differently, carrying a different sort of importance and urgency (although it need not). ${ }^{31}$ This is what I take to be the implied suggestion in a very a striking passage towards the end of The Claim of Reason:

Then I might put the question "Is there such a thing as soul-blindness?" in the following way: Is this [our form of civilization] [...] form of civilization being replaced by another? In particular, is it being replaced by one in which nothing that happens any longer strikes us as the objectification of subjectivity, as the act of an 
answerable agent, as the expression and satisfaction of human freedom, of human intention and desire? What has a beginning can have an end. If this future (civilization?) were effected its members would not be dissatisfied. They would have lost the concept of satisfaction. Then nothing would (any longer) give them the idea that living beings, human beings, could feel. So they would not (any longer) be human. They would not, for example, be frightened upon meeting others except in the sense, or under circumstances, in which they would be frightened upon encountering bears or storms, circumstances under which bears would be frightened. And of course particular forms of laughter and of amazement would also no longer be possible, ones which depend upon clear breaks between, say, machines and creatures (CR 468).

Cavell's picture here is so striking because it precisely draws out the stakes of what it would mean to see all others as devoid of agency: it would ultimately involve seeing ourselves as entirely devoid of agency; it shows the contours of what it would mean to affirm radical independence: namely, it would precisely require us to no longer see ourselves as agents. ${ }^{32}$ To see all others as devoid of agency - truly to see such a thing would require us to abrogate a variety of other highlights and lowlights in our moralvisual spectrum; indeed, it would require us to abrogate a particular view of ourselves. In the same way, incapacity and refusal to see certain others as like me (or as truly human or as more than a slave) merge together exactly because they are subject to countless other inflections and inputs, both individual and communal. This is what Cavell has in mind when he states that in seeing someone as a slave, the slave-owner can mean nothing "definite" (CR 376). The slave-owner, rather, appeals to a whole form of life, and all that such an appeal entails.

What I take Cavell to be implicitly stressing, then, when he writes that the slave-owner is "rather missing something about himself, or rather something about his connection with these people [slaves], his internal relation with them," is that the slave-owner illustrates the practical fragility of such internal relations and the theoretical complexity of how to understand this practical vulnerability: the myriad ways in which we can and do ignore, overlook, or devalue each other and the plethora of methods by which we attempt to justify, constitute, or fail to acknowledge such projects and claims. The interest (or promise) that Cavell's moral perfectionism holds for us is that it attempts to work within the framework of such failures (whether of reasons or acknowledgment, of institutions or individuals); Cavell's moral perfectionism should be understood as the means of navigating this fragility, not as a means of proposing it. ${ }^{33}$ This is what I take Cavell to mean when he writes in the introductory remarks to Conditions Handsome and Unhandsome, that "if there is a perfectionism not only compatible with democracy but necessary to it, it lies not in excusing democracy for its inevitable failure, or looking to rise above them, but in teaching how to respond to those failures, and to one's compromise by them, otherwise than by excuse or withdrawal." ${ }^{34}$

\section{Conclusion: Cavell and Evil}

What significance, does this have for Cavell's understanding of evil, or in Cavell's terms, monstrosity? When Cavell says that to understand Nazism would mean to understand it as a "human possibility; monstrous, unforgiveable, but not therefore the conduct of monsters" and that we do not "bear the right internal relation" to monsters, I believe he has in mind the idea that monstrosity or pure evil would not - indeed could not - be a part 
our form of life (CR 378). In making this argument for Cavell, I do not intend to suggest that Cavell would (or that we should) deny the existence of evil or evils, as he makes clear in the quote above (Nazism is monstrous), rather the denial is of evil as anything over and beyond a human possibility (i.e. pure evil or evil as a distinct, metaphysical force). On this argument, evils are always embedded in particular forms of life and thereby they are always anchored to fundamentally human, fundamentally understandable motives. This is not to say, of course, that we can always and immediately understand such motives no more than we can understand any other particular motives. It is often the case that our own motives, or the motives of others may be unavailable to us, whether because of a fundamental insensitivity to their origins or grounds or because of their complexity, or because of a variety of other possible factors. The only point I want to stress here is that potentially they are always available in the sense that they only exist through a complex framework of forms of life: of various materially saturated norms that themselves are interlaced with conceptions of good and evil, of human and inhuman, of monstrous and angelic, and so forth..$^{35}$

When Cavell states that, "mere morality is not designed to evaluate the behavior and interactions of monsters," he should be understood as making the same point that Hegel makes in his Lectures on Aesthetics. There, Hegel writes that: "evil in the abstract has no truth in itself and is of no interest." ${ }^{36}$ Contra Schelling and those would view evil as some sort of cosmic force, Hegel wants to argue that evil is really always a particular evil, ${ }^{37}$ embedded in a particular shape of spirit (indeed, it would not be too much to say "form of life" here) ${ }^{38}$ and answering to, evaluated by, and existing through a robust spiritual (geistige) backdrop. In this sense, to speak of evil as such would be akin to describing the act of a Hutu interhamawe or Khmer Rouge perpetrator of genocide as a force of nature: inscrutable, malevolent, and utterly inhuman. It would be precisely the picture that Cavell sketched above: where such things would no longer strike us as "the objectification of subjectivity." Indeed, they would ultimately be actions no longer attributable to subjects (in the same way that earthquakes or other natural disasters are not attributable to subjects), not because they are inhuman, but because they are not human ${ }^{39}$ Cavell's moral perfectionism, then, on one hand, shares with privation theories of evil the idea that evil is not some cosmic force standing over and beyond or apart from our forms of life. On the other hand, in opposition to such privation theories, it does posit evil as a genuine opposition to the good, but it is an opposition that is itself always staked, judged, delineated, and negotiated in light of a particular, concrete form of life. In short, then, evil has a genuine existence, but it is one that is perpetually responsive to our "whirl of organism" and which must be evaluated by a process that is somewhere between "natural science" and "natural history." 40

To conclude, I want briefly to acknowledge that all of this is not to say that various perpetrators through the course of history have not desired or aspired to see themselves as precisely not human (whether as more than human or fundamentally as a force of nature, but in either case, here opposed to inhuman). Indeed, Hannah Arendt famously argued that (at least some, if not many of) the perpetrators of the Nazi genocide saw themselves as superfluous as their victims. As she wrote in Origins of Totalitarianism: "The manipulators of this system believe in their own superfluousness as much as in that of all others, and the totalitarian murderers are all the more dangerous because they do not care if they themselves are alive or dead, if they ever lived or never were born." ${ }^{41}$ I would take Cavell to be quite sympathetic to Arendt's line of argument, ${ }^{42}$ with the 
understanding that this fantasy of superfluousness must always be understood as a human possibility, one with a distinct historical axis, whether ideological, material, or some combination of these or a host of others, others which are and, again, can only be human, all-too-human.

Indeed, Cavell's moral perfectionism precisely bars the means by which the question of whether evil is a privation or a positive force tends to arise in the first place. Evil on such a view, is a human possibility, akin to justice or vengeance or respect: it is a sort of claim that we make to, for, and perhaps in opposition to others. It is, then, like a variety of other sorts of claims: a claim to reason and part of the search for reason. On such a proposal, then, seeing it as a privation looks especially useless, since it no more makes sense to see evil as a privation than it does to see any of our other claims as a privation. (A privation of what? The only privation that could exist on such a picture would be the empty, hollow silence of the lack of agency that Cavell describes.) Similarly, seeing it as a positive object also makes no more sense than seeing any other claims as distinctly positive. (It is no more and no less a positive object than the object of any other claim: always open to revision and negotiated by our forms of life.) Either picture would be a picture that would present ourselves to ourselves as more than human; it would somehow erase the fact of our humanity, our finitude, by making us either too evil or not evil enough.

\section{NOTES}

1. Stanley Cavell, The Claim of Reason: Wittgenstein, Skepticism, Morality, and Tragedy (Oxford, Oxford University Press, 1979). Cited as CR in the body of the text.

2. An emblematic representation of the former is F.W.J. Schelling, Philosophical Investigations into the Essence of Human Freedom, trans. Jeff Love and Johannes Schmidt (Buffalo, State University of New York Press, 2007). A quintessential example of the latter is Augustine, Confessions (London, Penguin, 1961)

3. One occurrence (CR 370), which I don't bother quoting is itself a quote from Wittgenstein; I will turn to the significance of this shortly.

4. G.E. Moore, "External and Internal Relations," Proceedings of the Aristotlean Society 20 (1919), 40.

5. As Russell will write: "The doctrine of internal relations held that every relation between two terms expresses, primarily, intrinsic properties of the two terms, and, in ultimate analysis, a property of the whole which the two compose." See Bertrand Russell, My Philosophical Development (London, Unwin Hyman, 1995), 54. For an account of this period, see Peter Hylton, Russell, Idealism, and the Emergence of Analytic Philosophy (Oxford, Oxford University Press, 1992). See also Ronald Jager, The Development of Bertrand Russell's Philosophy (London, Routledge, 2004), 61-87.

6. For an overview, see Marie McGinn, "Wittgenstein and Internal Relations," European Journal of Philosophy (2009). Roughly, the debate is over what sort of understanding of "internal relations" Wittgenstein is committed to in the early work. I don't enter into this discussion except in order to elaborate Wittgenstein's understanding of the notion in his later work, which is the work that holds the most significance for Cavell. 
7. Ludwig Wittgenstein, Tractatus Logico-Philosophicus, trans. B. F. McGuinness and D. F. Pears (London, Routledge, 1974), 127. It may or may not be that this issue is related to the so called "color-exclusion" problem. For an argument to this effect, see Don Sievert, "Another Look at Wittgenstein on Color Exclusion," Synthese 78, no. 3 (1989).

8. Ludwig Wittgenstein, Philosophical Investigations, trans. G.E.M. Anscombe (Upper Sadle, Prentice Hall, 1958), 212e.

9. Ibid., 213e.

10. Bertrand Russell, "On the Nature of Truth," Proceedings of the Aristotlean Society 7 (1906-07), 38.

11. Cf. Terry Pinkard, "Innen, Aussen und Lebensformen: Hegel und Wittgenstein," in Hegels Erbe (Frankfurt am Main, Suhrkamp, 2004), 267.

12. Ludwig Wittgenstein, Lectures on the Foundations of Mathematics, ed. Cora Diamond (Ithaca, Cornell University Press, 1976), 73.

13. John McDowell, Mind and World (Cambridge, Harvard University Press, 1996), 11.

14. I will elaborate Cavell's understanding of this notion shortly. A valuable place to look is in Cavell's brief discussion in Stanley Cavell, This New yet Unapproachable America: Lectures after Emerson after Wittgenstein (Albuquerque, Living Batch Press, 1989), 40-5.

15. Ludwig Wittgenstein, On Color, trans. Linda McAlister and Margerete Schattle (Oxford, Blackwell, 1977). Quoted in Nicholas F.Gier, Wittgenstein and Phenomenology (Buffalo, State University of New York Press, 1981), 86. Gier's chapter ("Holism and Internal Relations") makes, from a different perspective, the same point I have been developing here.

16. Wittgenstein, Philosophical Investigations, $213 \mathrm{e}$.

17. Wittgenstein, Philosophical Investigations, $214 \mathrm{e}$.

18. Wittgenstein, Philosophical Investigations, $214 \mathrm{e}$.

19. Wittgenstein, Philosophical Investigations, $214 \mathrm{e}$.

20. I say "all of the" because it would not be too implausible to view the history of a certain brand of post- Kantian philosophy (importantly one to which Cavell himself belongs) as centering on such issues. On this point, see Paul W. Franks, "The Discovery of the Other: Cavell, Fichte, and Skepticism," Common Knowledge 5, no. 2 (1996).

21. For an explicit connection between "practices" and "forms of life," see Jeffrey Thomas Price, Language and Being in Wittgenstein's Philosophical Investigations (New York: Walter De Gruyter Inc, 1973), 83.

22. For an elaboration of this point, see The Claim of Reason and (particularly the second essay in) Stanley Cavell, Conditions Handsome and Unhandsome (Chicago: University of Chicago Press, 1990). See also John McDowell, "Wittgenstein on Following a Rule," in Mind, Value, and Reality (Cambridge, Cambridge University Press, 1998).

23. Stanley Cavell, Must We Mean What We Say?: A Book of Essays (Cambridge University Press, 2002), 52 .

24. There arises here, I believe an interesting question about what sorts of things we can and cannot say about how our forms of life change. This question pushes us towards manifestly Hegelian sorts of question. For an elabo- ration of what is at stake between Wittgenstein (Cavell) and Hegel on this point, see Pinkard, "Innen, Aussen und Lebensformen: Hegel und Wittgenstein." For an elaboration of the sorts of questions I have in mind, see especially the conclusion of Robert B. Pippin, Hegel's Practical Philosophy: Rational Agency as Ethical Life (Cambridge, Cambridge University Press, 2008).

25. Wittgenstein, On Color, 46.

26. Wittgenstein, Philosophical Investigations, 90e. Cf. CR 379: "For surely nothing other than a human being, or something awfully like a human being, could simulate human responses?"

27. And, again, although there are many more questions about the mechanics of this relationship, what must be stressed is that this is not the mere agreements of a community. On this point, see footnote 22 . 
28. What I mean here is the question is whether one should read Cavell along a more "Levinasian" direction, where acknowledgment of the other is understood in a non-dialectical fashion, or where he is to be understood in a more, e.g., Fichtean (Hegelian) understanding where it is understood as a dialectical one. Derrida raises this issue vis-à-vis the other most forcefully with his discussion of Lévinas and Husserl on the other in Jacques Derrida, "Violence and Metaphysics," in Writing and Difference (Baltimore, Johns Hopkins University, 1978).

29. Wittgenstein, Philosophical Investigations, 213e.

30. Iris Murdoch elaborates a very similar vision of morality in Iris Murdoch, "Vision and Choice in Morality," in Existentialists and Mystics (New York, Penguin, 1997). See especially the concluding pages of her essay.

31. I am reminded here of a poignant scene in Robert Benigni's Life is Beautiful (1997), where the Nazi, Lessing, is obsessed with finding an answer to a riddle as opposed to seeing Guido as more than the possibility of an answer to the riddle.

32. Although I do not pursue it here, I think the picture that Cavell presents here has much in common with the picture that Horkheimer and Adorno present in the first essay of Max Horkheimer and Theodor W. Adorno, Dialectic of Enlightenment, Philosophical Fragments, ed. Mieke Bal and Hent de Vries, trans. Edmund Jephcott, Cultural Memory in the Present (Stanford, Stanford University Press, 2002). Cavell's comments at the end of this section about myth are in this proposed analogue especially suggestive.

33. This is what I had meant in my introduction when I said that I believe Cavell's moral perfectionism follows from his notion of internal relations, not the other way around. I take this to be significant because it is not the case that Cavell's moral perfectionism is moralizing in that proscribes a particular epistemology, but rather the epistemology calls for a certain type of morality.

34. Cavell, Conditions Handsome and Unhandsome, 18.

35. This is what I take Cavell explicitly to refer to in the third essay of Ibid. As Cavell points out that Marquis (of The Marquis of O) states to the Count that he ultimately "would not have looked like a devil to her (when he appeared as the father of the child) if he had not seemed like an angel to her at his first appearance." Cavell, Conditions Handsome and Unhandsome, 118.

36. G. W. F. Hegel, Hegel's Aesthetics: Lectures on Fine Art, trans. T. M. Knox (Oxford, Oxford University Press, 1975), 2, 1212.

37. Cf. Robert B. Pippin, Idealism as Modernism: Hegelian Variations (Cambridge, Cambridge University Press, 1997), 412.

38. On this point, see Terry Pinkard, "What Is a Shape of Spirit?," in The Phenomenology of Spirit: A Critical Guide, ed. Dean Moyar and Michael Quante (Cambridge, Cambridge University Press, 2008).

39. Cavell, then, initially appears to be uninterested in extreme evils like the Nazi genocide not because they are limit cases which are uninteresting, but precisely because they are often taken to be limit cases which display a fundamental lack of humanity (as opposed to a presence of inhumanity). Cavell's point is that such cases are of no interest precisely if they are taken to be limit cases, because they are pushed beyond the realm of human action (and would be of no more interest to the account of The Claim of Reason than natural disasters). They are not, however, uninteresting intrinsically.

40. See Wittgenstein, Philosophical Investigations, $230 \mathrm{e}$.

41. Hannah Arendt, The Origins of Totalitarianism (London, André Deutsch, 1986), 459. Note that Arendt's argument is not that because Nazi actors viewed themselves in this way, their motives are fundamentally not understandable as human ones. Rather, her argument is that totalitarianism presents new sort of human possibility. Put another way, Arendt's debate with Kant is not on the point that all motives are comprehensible, but on the point that Kant's choice 
between either the categorical imperative (morality) or self-interest/self-love (immortality) does not cover all the options.

42. Indeed, I don't think it would be too difficult to map Cavell's skeptical recital onto Arendt's framework in "Total Domination" - but that would be a project for another essay.

\section{ABSTRACTS}

In this article, I examine Cavell's understanding and deployment of the categories of 'evil' and the 'monstrous' in The Claim of Reason. Arguing that these notions cannot be understood apart from Cavell's reliance on the notion of an 'internal relation,' I trace this notion to its Wittgensteinian roots. Ultimately, I show that Cavell's view of evil allows us to navigate between two horns of a classic dilemma in thinking about evil: it allows us to see evil as neither a privation nor as a positive force with supra-human potency. 